\title{
Efficacy of Insecticides Against Spodoptera frugiperda (Smith, 1797)
}

\author{
Fabrício O. Fernandes ${ }^{1}$, Jéssica A. Abreu ${ }^{2}$, Lucas M. Christ ${ }^{2} \&$ Ana Paula S. A. Rosa ${ }^{3}$ \\ ${ }^{1}$ Department of Plant Protection, Paulista State University “Júlio de Mesquita Filho”, Jaboticabal, Brazil \\ ${ }^{2}$ Department of Plant Protection, Federal University of Pelotas, Pelotas, Brazil \\ ${ }^{3}$ Department of Entomology, Embrapa Temperate Weather, Pelotas, Brazil \\ Correspondence: Fabrício O. Fernandes, Department of Plant Protection, Paulista State University "Júlio de \\ Mesquita Filho", Jaboticabal, Brazil. E-mail: fabriciof9@gmail.com
}

Received: September 20, 2018

Accepted: October 26, 2018

Online Published: December 15, 2018

doi:10.5539/jas.v11n1p494

URL: https://doi.org/10.5539/jas.v11n1p494

\begin{abstract}
The Brazil's economy is supported by agribusiness, however, the continuous cycle of food production and favorable climate contributes to the incidence of pest insects all year round. The fall armyworm Spodoptera frugiperda (Smith, 1797) (Lepidoptera: Noctuidae) is considered the main insect in the corn crop, due to voracity of the caterpillars and occurrence throughout the crop cycle. Therefore, the chemical control has been demanded considerably, causing emergence of populations resistant to the different products, as well as implications in the environment. Thus, studies are needed to evaluate the efficiency of chemical insecticide control according to the susceptibility and the stages of biological development of the pest. The objective of this work was to evaluate the performance of isolated and combined insecticides for the control of $S$. frugiperda caterpillars under laboratory conditions. In the residual and direct contact bioassays, 8 treatments with 5 replications were used in a completely randomized design, performed with $2^{\text {nd }}$ and $5^{\text {th }}$ instar. The results showed that by residual contact after 72 hours, clofenapir + zeta-cypermethrin treatment had $100 \%$ efficacy in the mortality of both instars. When applied via direct contact 72 hours later, the combined treatments showed an efficiency above $80 \%$. However, for an integrated pest management program, where it was recommended the association of different control tactics, the management of insecticides with clofenapir + zeta-cypermethrin was effective with $100 \%$ control efficiency in both instars.
\end{abstract}

Keywords: chemical control, leafhopper caterpillar, insecticide management, insecticide rationing, insect resistance, application technology

\section{Introduction}

The Brazil's economy is supported by agribusiness, and this fact is attributed to the availability of water, favorable climate, arable land and technology that enables the country to produce all year. However, the continuous cycle of food production and the favorable climate contribute to the incidence of pests which, in view of the circumstance, provides, in many cases, high utilization of chemical control (Belluzzo et al., 2014; Melo et al., 2018). The domestic sales of insecticides in the 2016/2017 harvest reached levels of more than 551 thousand tons of products, with the states of Mato Grosso (104,901.05 tons), São Paulo (76.44,55 tons), Paraná (72,212.38 tons) and Rio Grande do Sul (63,352.27 tons), the largest consumers (IBAMA, 2017).

The corn is the second most representative product in the country $\left(4.967,00 \mathrm{Kg} \cdot \mathrm{ha}^{-1}\right)$, providing subsidies to the industry as raw material for human and animal feed, depending on the quantity and nutritional quality of the grain (CONAB, 2018; Rolim et al., 2018). However, in the corn crop, the fall armyworm Spodoptera frugiperda (Smith, 1797) (Lepidoptera: Noctuidae) promotes significant losses in production, by voracity of the caterpillars and occurrence throughout the crop cycle. With reductions in productivity around $34 \%$ to $40 \%$ depending on the stage of development of the plant (Cruz, 2002).

Thus, the control of this insect has demanded a high number of insecticide applications, causing populations resistant to the different products (Diez-Rodríguez \& Omoto, 2001; Ahmad et al., 2018; Wang et al., 2018), as well as negative implications for the environment (Michelotto et al., 2017).

Therefore, it is necessary to carry out studies that evaluate the efficiency of control of chemical insecticides on the target insect, since the relative adaptation of a population may vary according to the stages of development 
(Cruz, 2002). Studies evaluating Helicoverpa armigera (Hübner, 1909) (Lepidoptera: Noctuidae) have demonstrated that newborn caterpillars can be easily killed by insecticides, while efficiency decreases when the application is at an advanced stage of development. In addition, it is necessary to consider that, under field conditions, the generations are not synchronized, occurring, at the same time and place, insects of different stages of development (Lucchini, 1977).

As an alternative, the rotation of active ingredients is a management strategy for insect pest control, however, it is important to consider whether there is cross-resistance and/or incompatibility between insecticides. These studies are important because, in addition to elucidating the basic aspects involved in the resistance to chemical groups of insecticides, they provide important information for the management of the species (Guedes \& Oliveira, 2002; Sosa-Gómez \& Omoto, 2012).

Considering the importance of the carcass caterpillar, and the lack of studies on the performance of the chemical control used in corn cultivation, the objective of this work was to evaluate the performance of isolated and combined insecticides for the control of $S$. frugiperda caterpillars under laboratory conditions.

\section{Materials and Methods}

The experiments were conducted at the Embrapa Temperate Weather Bioefficiency Nucleus in an air conditioned room at $25 \pm 1^{\circ} \mathrm{C}$, RH of $70 \pm 10 \%$ and 12 hours of photophase.

\subsection{Procurement of Plants}

Corn seeds from AG 9045 were planted in 20-liter plastic pots containing natural substrate based on humus, fiber and clay (West Garden ${ }^{\circledR}$ ), and then kept in a greenhouse. The corn plants reaching the phenological stage V.4 (approximately 25 days) were used in laboratory experiments as a food substrate of caterpillars.

\subsection{Insect Collection and Breeding}

The insects were collected at the Terras Baixas Experimental Station in the municipality of Capão do Leão, Rio Grande do Sul, BR. (S 31 ${ }^{\circ} 49.268^{\prime}$ S, 52 $27.472^{\prime}$ W, altitude $7 \mathrm{~m}$ ) in corn crops in the 2015/2016 harvest, Greene et al. (1976), for 2 generations. From this, 200 eggs of $S$. frugiperda were collected, packed in Petri dishes $(9 \mathrm{~cm}$ $\varnothing)$, with filter paper moistened with sterile distilled water at the bottom and at the top perforated plastic film (PVC) with a pin. The material was kept in an air conditioned room at $25 \pm 1{ }^{\circ} \mathrm{C}$, RH of $70 \pm 10 \%$ and photophase of 12 hours until hatching of the caterpillars. Residual contact and direct contact bioassays were used for $2^{\text {nd }}$ and $5^{\text {th }}$ instars caterpillars fed a natural diet.

\subsection{Residual Contact Bioassay}

The corn leaves were cut into disks $(4 \mathrm{~cm} \varnothing)$ and immersed in the treatments for 20 seconds (Table 1). The treatments that presented more than one product after the application of the first product were placed on a bench to wait for the evaporation of excess moisture and after being immersed in another treatment. The leaves submitted to the treatments were conditioned in containers of polystyrene with capacity of $100 \mathrm{ml}$ and inoculated the caterpillars of $2^{\text {nd }}$ or $5^{\text {th }}$ instar, being 5 repetitions with 4 caterpillars, totaling 20 caterpillars per treatment. The treatments were kept in an air conditioned room at $25 \pm 1{ }^{\circ} \mathrm{C}$, RH of $70 \pm 10 \%$ and $12 \mathrm{~h}$ of photophase.

\subsection{Direct Contact Bioassay}

The spray was carried out in a Potter's Tower (Burkard Scientific Uxbridge, UK), calibrated at a pressure of 10 lb.pol-2 with application of $500 \mu \mathrm{l}$ of insecticidal spray (Table 1) onto $2^{\text {nd }}$ or $5^{\text {th }}$ instar caterpillars. After spraying, the $2^{\text {nd }}$ or $5^{\text {th }}$ instar caterpillars were placed in a polystyrene container with a capacity of $100 \mathrm{ml}$ containing discs $(4 \mathrm{~cm} \varnothing)$ of the corn leaf, 5 replicates with 4 caterpillars, totaling 20 caterpillars per treatment. The treatments were kept in an air conditioned room at $25 \pm 1{ }^{\circ} \mathrm{C}$, $\mathrm{RH}$ of $70 \pm 10 \%$ and $12 \mathrm{~h}$ of photophase. 
Table 1. Active ingredient, mode of action and dose of insecticides used in corn crop on the control of Spodotera frugiperda caterpillars

\begin{tabular}{ll}
\hline Active Ingredient & Mode of Action \\
\hline Chlorantraniliprole & Rannodyne receptor modulators \\
Chlorantraniliprole + Zeta-Cypermethrin & Rannodyne receptor modulators + Sodium channel modulators \\
Flubendiamide & Rannodyne receptor modulators \\
Flubendiamide + Zeta-Cypermethrin & Rannodyne receptor modulators + Sodium channel modulators \\
Chlorfenapyr & De-couplers of oxidative phosphorylation via disruption of the proton gradient $\quad 500 \quad 100+80$ \\
Chlorfenapyr + Zeta-Cypermethrin & De-couplers of oxidative phosphorylation via disruption of the proton gradient \\
& + Sodium channel modulators +80 \\
Zeta-Cypermethrin & Sodium channel modulators \\
Control & Control \\
\hline
\end{tabular}

Note. ${ }^{*} \mathrm{~mL} \mathrm{ha}^{-1}$.

\subsection{Experimental Design}

The design used was completely randomized design (CRD) and the evaluations were performed 4, 24, 72, 120 , 168 hours after treatment (HAT). The data were submitted to analysis of variance (Anova) and the means were compared by the Tukey test at 5\% significance (SAS University, 2014). The control efficiency calculated through corrected mortality, from the Abbott formula (1925) described below:

$$
C E(\%)=[(n T-n t) / n T] \times 100
$$

where, $\mathrm{nT}=$ live insects in the control; $\mathrm{nt}=$ live insects in the treatment.

\section{Results}

\subsection{Residual Contact Bioassay}

In the experiment applied by residual contact in $2^{\text {nd }}$ instar caterpillars of $S$. frugiperda, treatments chlorfenapyr $(100 \%)$, chlorfenapyr + zeta-cypermethrin $(100 \%)$, zeta-cypermethrin $(95 \%)$ and flubendiamide + zeta-cypermethrin (75\%) achieved the best controls differing from the 4 HAT control. Similarly, 24 HAT did not change the efficiency of the applied treatments (Table 2).

In the evaluations carried out 72 HAT it was observed that chlorantraniliprole treatments and the combination of chlorantraniliprole + zeta-cypermethrin promoted an increase of control efficiency in $2^{\text {nd }}$ instar caterpillars. However, when considering the observed observation 120 HAT the chlorantraniliprole treatment presented a significant increase in the control of $S$. frugiperda. To the combined treatment chlorantranilirpole + zeta-cypermethrin there was no significant increase in mortality. In the last performed HAT 168, chlorfenapyr, chlorfenapyr + zeta-cypermethrin and zeta-cypermethrin were the most efficient treatments (100\%) (Table 2).

When $5^{\text {th }}$ instar caterpillars of $S$. frugiperda were submitted via residual contact to the chemical treatments, a distinct performance was observed, with chlorantraniliprole controlling only $15 \%$ of the 24 HAT target insects. The evaluation performed 72 HAT evidenced the efficiency of the treatment clofernapir + zeta-cypermethrin $(100 \%)$, differing significantly from the control (Table 2).

In the 168 HAT evaluation, only the flubendiamide treatment obtained the lowest control efficiency, differing from all treatments in $S$. frugiperda $5^{\text {th }}$ instar caterpillars (Table 2).

\subsection{Direct Contact Bioassay}

In the experiment applied by direct contact in $2^{\text {nd }}$ instar caterpillars of $S$. frugiperda, the results were different from the previous ones (residual contact). The treatment with zeta-cypermethrin reached $55 \%$ efficiency in the control of the target insect, differing significantly from the control in 4 and 24 HAT, however, without differing from the combined treatment with flubendiamide + zeta-cypermethrin. The control over $80 \%$ occurred in 72 HAT, in the treatments chlorantraniliprole, chlorantraniliprole + zeta-cypermethrin, flubendiamide + zeta-cypermethrin, chlorfenapyr, chlorfenapyr + zeta-cypermethrin and zeta-cypermethrin. In the evaluations performed 120 HAT and 168 HAT, only flubendiamide did not reach $80 \%$ of control efficiency (Table 3).

The efficiency of $80 \%$ or higher observed when the insecticides were applied via direct contact on S. frugiperda $5^{\text {th }}$ instar caterpillars was attributed to the treatments chlorantraniliprole, chlorantraniliprole + zeta-cypermethrin, flubendiamide + zeta-cypermethrin, chlorfenapyr and chlorfenapyr + zeta-cypermethrin 4 HAT (Table 3). 
At the end of the evaluation, although all treatments differed significantly from the control, zeta-cypermethrin was below the desired level for control of $S$. frugiperda caterpillars (Table 3).

Table 2. Mean $(\mathrm{X} \pm \mathrm{SE})$ of living caterpillars and control efficiency (CE\%) of Spodotera frugiperda caterpillars at $4,24,72,120,168$ hours after the treatment (HAT) via residual contact

\begin{tabular}{|c|c|c|c|c|c|c|c|c|c|c|}
\hline \multicolumn{11}{|l|}{$2^{\text {nd }}$ instar } \\
\hline Treatments & 4 HAT & CE $(\%)$ & 24 HAT & CE $(\%)$ & 72 HAT & $\mathrm{CE}(\%)$ & 120 HAT & $\mathrm{CE}(\%)$ & 168 HAT & $\mathrm{CE}(\%)$ \\
\hline Chlorantraniliprole & $4.5 \pm 0.05 \mathrm{~A}^{1}$ & 10 & $4.5 \pm 0.05 \mathrm{~A}$ & 10 & $3.0 \pm 1.22 \mathrm{AB}$ & 40 & $0.3 \pm 0.25 \mathrm{BC}$ & 95 & $0.3 \pm 0.25 \mathrm{BC}$ & 95 \\
\hline Chlorantraniliprole + Zeta-cypermethrin & $3.8 \pm 1.25 \mathrm{AB}$ & 25 & $3.8 \pm 1.25 \mathrm{AB}$ & 25 & $0.7 \pm 0.25 \mathrm{BC}$ & 85 & $0.7 \pm 0.25 \mathrm{BC}$ & 85 & $0.7 \pm 0.25 \mathrm{BC}$ & 85 \\
\hline Flubendiamide & $3.0 \pm 0.91 \mathrm{ABC}$ & 40 & $3.0 \pm 0.91 \mathrm{ABC}$ & 40 & $3.0 \pm 0.91 \mathrm{AB}$ & 40 & $2.3 \pm 1.11 \mathrm{~B}$ & 55 & $1.5 \pm 0.65 \mathrm{~B}$ & 70 \\
\hline Flubendiamide + Zeta-cypermethrin & $1.3 \pm 0.25 \mathrm{BCD}$ & 75 & $1.3 \pm 0.25 \mathrm{BCD}$ & 75 & $1.3 \pm 0.25 \mathrm{BC}$ & 75 & $0.5 \pm 0.29 \mathrm{C}$ & 90 & $0.5 \pm 0.29 \mathrm{BC}$ & 90 \\
\hline Chlorfenapyr & $0.0 \pm 0.00 \mathrm{D}$ & 100 & $0.0 \pm 0.00 \mathrm{D}$ & 100 & $0.0 \pm 0.00 \mathrm{C}$ & 100 & $0.0 \pm 0.00 \mathrm{C}$ & 100 & $0.0 \pm 0.00 \mathrm{C}$ & 100 \\
\hline Chlorfenapyr + Zeta-cypermethrin & $0.0 \pm 0.00 \mathrm{D}$ & 100 & $0.0 \pm 0.00 \mathrm{D}$ & 100 & $0.0 \pm 0.00 \mathrm{C}$ & 100 & $0.0 \pm 0.00 \mathrm{C}$ & 100 & $0.0 \pm 0.00 \mathrm{C}$ & 100 \\
\hline Zeta-cypermethrin & $0.3 \pm 0.25 \mathrm{CD}$ & 95 & $0.3 \pm 0.25 \mathrm{D}$ & 95 & $0.3 \pm 0.25 \mathrm{C}$ & 95 & $0.3 \pm 0.25 \mathrm{C}$ & 95 & $0.0 \pm 0.00 \mathrm{C}$ & 100 \\
\hline Control & $5.0 \pm 0.00 \mathrm{~A}$ & - & $5.0 \pm 0.00 \mathrm{~A}$ & - & $5.0 \pm 0.00 \mathrm{~A}$ & - & $5.0 \pm 0.00 \mathrm{~A}$ & - & $5.0 \pm 0.00 \mathrm{~A}$ & - \\
\hline $\mathrm{Cv}(\%)$ & 8.05 & & 10.05 & & 7.78 & & 6.98 & & 8.90 & \\
\hline \multicolumn{11}{|l|}{$5^{\text {th }}$ instar } \\
\hline Treatments & 4 HAT & CE $(\%)$ & 24 HAT & $\mathrm{CE}(\%)$ & 72 HAT & $\mathrm{CE}(\%)$ & 120 HAT & CE $(\%)$ & 168 HAT & CE $(\%)$ \\
\hline Chlorantraniliprole & $4.3 \pm 0.75 \mathrm{~A}^{1}$ & 15 & $4.3 \pm 0.75 \mathrm{~A}$ & 15 & $2.0 \pm 0.91 \mathrm{BCD}$ & 60 & $0.0 \pm 0.00 \mathrm{C}$ & 100 & $0.0 \pm 0.00 \mathrm{C}$ & 100 \\
\hline Chlorantraniliprole + Zeta-cypermethrin & $5.0 \pm 0.00 \mathrm{~A}$ & 0 & $5.0 \pm 0.00 \mathrm{~A}$ & 0 & $3.0 \pm 0.41 \mathrm{ABC}$ & 40 & $0.7 \pm 0.48 \mathrm{C}$ & 85 & $0.2 \pm 0.25 \mathrm{C}$ & 95 \\
\hline Flubendiamide & $5.0 \pm 0.00 \mathrm{~A}$ & 0 & $5.0 \pm 0.00 \mathrm{~A}$ & 0 & $3.5 \pm 0.29 \mathrm{AB}$ & 30 & $2.7 \pm 0.25 \mathrm{~B}$ & 45 & $2.7 \pm 0.25 \mathrm{~B}$ & 45 \\
\hline Flubendiamide + Zeta-cypermethrin & $5.0 \pm 0.00 \mathrm{~A}$ & 0 & $5.0 \pm 0.00 \mathrm{~A}$ & 0 & $1.8 \pm 0.25 \mathrm{BCD}$ & 65 & $0.7 \pm 0.25 \mathrm{C}$ & 85 & $0.0 \pm 0.00 \mathrm{C}$ & 100 \\
\hline Chlorfenapyr & $5.0 \pm 0.00 \mathrm{~A}$ & 0 & $5.0 \pm 0.00 \mathrm{~A}$ & 0 & $1.3 \pm 1.25 \mathrm{BCD}$ & 75 & $0.0 \pm 0.00 \mathrm{C}$ & 100 & $0.0 \pm 0.00 \mathrm{C}$ & 100 \\
\hline Chlorfenapyr + Zeta-cypermethrin & $5.0 \pm 0.00 \mathrm{~A}$ & 0 & $5.0 \pm 0.00 \mathrm{~A}$ & 0 & $0.0 \pm 0.00 \mathrm{D}$ & 100 & $0.0 \pm 0.00 \mathrm{C}$ & 100 & $0.0 \pm 0.00 \mathrm{C}$ & 100 \\
\hline Zeta-cypermethrin & $4.0 \pm 0.00 \mathrm{~A}$ & 0 & $5.0 \pm 0.00 \mathrm{~A}$ & 0 & $0.2 \pm 0.25 \mathrm{CD}$ & 95 & $0.2 \pm 0.25 \mathrm{C}$ & 95 & $0.2 \pm 0.25 \mathrm{C}$ & 95 \\
\hline Control & $5.0 \pm 0.00 \mathrm{~A}$ & - & $5.0 \pm 0.00 \mathrm{~A}$ & - & $5.0 \pm 0.00 \mathrm{~A}$ & - & $5.0 \pm 0.00 \mathrm{~A}$ & - & $5.0 \pm 0.00 \mathrm{~A}$ & - \\
\hline $\mathrm{Cv}(\%)$ & 5.24 & & 5.24 & & 6.22 & & 7.44 & & 9.69 & \\
\hline
\end{tabular}

Note. ${ }^{1}(\mathrm{X} \pm \mathrm{SE})=$ Average number of caterpillars \pm Standard error. ${ }^{2}$ Means followed by the same letter in column do not differ by Tukey test $(\mathrm{P}<0.05)$. CV $(\%)=$ Coefficient of variation.

Table 3. Mean $(\mathrm{X} \pm \mathrm{SE})$ of living caterpillars and control efficiency (CE\%) of Spodotera frugiperda caterpillars at $4,24,72,120,168$ hours after the treatment (HAT) via direct contact

\begin{tabular}{|c|c|c|c|c|c|c|c|c|c|c|}
\hline \multicolumn{11}{|l|}{$2^{\text {nd }}$ instar } \\
\hline Treatments & 4 HAT & $\mathrm{CE}(\%)$ & 24 HAT & $\mathrm{CE}(\%)$ & 72 HAT & $\mathrm{CE}(\%)$ & 120 HAT & $\mathrm{CE}(\%)$ & 168 HAT & CE $(\%)$ \\
\hline Chlorantraniliprole & $5.0 \pm 0.00 \mathrm{~A}^{1}$ & 0 & $5.0 \pm 0.00 \mathrm{~A}$ & 0 & $0.0 \pm 0.00 \mathrm{C}$ & 100 & $0.0 \pm 0.00 \mathrm{C}$ & 100 & $0.0 \pm 0.00 \mathrm{C}$ & 100 \\
\hline Chlorantraniliprole + Zeta-cypermethrin & $5.0 \pm 0.00 \mathrm{~A}$ & 0 & $5.0 \pm 0.00 \mathrm{~A}$ & 0 & $0.3 \pm 0.25 \mathrm{C}$ & 95 & $0.3 \pm 0.25 \mathrm{BC}$ & 95 & $0.3 \pm 0.25 \mathrm{C}$ & 95 \\
\hline Flubendiamide & $5.0 \pm 0.00 \mathrm{~A}$ & 0 & $5.0 \pm 0.00 \mathrm{~A}$ & 0 & $0.3 \pm 0.25 \mathrm{~B}$ & 50 & $1.5 \pm 0.87 \mathrm{~B}$ & 70 & $1.3 \pm 0.48 \mathrm{~B}$ & 75 \\
\hline Flubendiamide + Zeta-cypermethrin & $4.3 \pm 0.75 \mathrm{AB}$ & 15 & $4.3 \pm 0.75 \mathrm{AB}$ & 15 & $0.8 \pm 0.25 \mathrm{C}$ & 85 & $0.0 \pm 0.00 \mathrm{C}$ & 100 & $0.0 \pm 0.00 \mathrm{C}$ & 100 \\
\hline Chlorfenapyr & $5.0 \pm 0.00 \mathrm{~A}$ & 0 & $5.0 \pm 0.00 \mathrm{~A}$ & 0 & $0.0 \pm 0.00 \mathrm{C}$ & 100 & $0.0 \pm 0.00 \mathrm{C}$ & 100 & $0.0 \pm 0.00 \mathrm{C}$ & 100 \\
\hline Chlorfenapyr + Zeta-cypermethrin & $5.0 \pm 0.00 \mathrm{~A}$ & 0 & $5.0 \pm 0.00 \mathrm{~A}$ & 0 & $0.0 \pm 0.00 \mathrm{C}$ & 100 & $0.0 \pm 0.00 \mathrm{C}$ & 100 & $0.0 \pm 0.00 \mathrm{C}$ & 100 \\
\hline Zeta-cypermethrin & $2.3 \pm 0.00 \mathrm{~B}$ & 55 & $2.3 \pm 0.00 \mathrm{~B}$ & 55 & $0.0 \pm 0.00 \mathrm{C}$ & 100 & $0.0 \pm 0.00 \mathrm{C}$ & 100 & $0.0 \pm 0.00 \mathrm{C}$ & 100 \\
\hline Control & $5.0 \pm 0.00 \mathrm{~A}$ & - & $5.0 \pm 0.00 \mathrm{~A}$ & - & $5.0 \pm 0.00 \mathrm{~A}$ & - & $5.0 \pm 0.00 \mathrm{~A}$ & - & $5.0 \pm 0.00 \mathrm{~A}$ & - \\
\hline $\mathrm{Cv}(\%)$ & 5.38 & & 5.38 & & 7.34 & & 5.54 & & 7.01 & \\
\hline \multicolumn{11}{|l|}{$5^{\text {th }}$ instar } \\
\hline Treatments & 4 HAT & CE $(\%)$ & 24 HAT & $\mathrm{CE}(\%)$ & 72 HAT & $\mathrm{CE}(\%)$ & 120 HAT & $\mathrm{CE}(\%)$ & 168 HAT & CE $(\%)$ \\
\hline Chlorantraniliprole & $0.0 \pm 0.00 \mathrm{C}^{1}$ & 100 & $0.0 \pm 0.00 \mathrm{C}$ & 100 & $0.0 \pm 0.00 \mathrm{C}$ & 100 & $0.0 \pm 0.00 \mathrm{C}$ & 100 & $0.0 \pm 0.00 \mathrm{C}$ & 100 \\
\hline Chlorantraniliprole + Zeta-cypermethrin & $1.0 \pm 0.58 \mathrm{BC}$ & 80 & $1.0 \pm 0.58 \mathrm{BC}$ & 80 & $0.0 \pm 0.00 \mathrm{C}$ & 100 & $0.0 \pm 0.00 \mathrm{C}$ & 100 & $0.0 \pm 0.00 \mathrm{C}$ & 100 \\
\hline Flubendiamide & $2.0 \pm 0.41 \mathrm{~B}$ & 60 & $2.0 \pm 0.41 \mathrm{~B}$ & 60 & $1.3 \pm 0.63 \mathrm{BC}$ & 75 & $1.0 \pm 0.41 \mathrm{C}$ & 80 & $1.0 \pm 0.41 \mathrm{C}$ & 80 \\
\hline Flubendiamide + Zeta-cypermethrin & $0.0 \pm 0.00 \mathrm{C}$ & 100 & $0.0 \pm 0.00 \mathrm{C}$ & 100 & $0.0 \pm 0.00 \mathrm{C}$ & 100 & $0.0 \pm 0.00 \mathrm{C}$ & 100 & $0.0 \pm 0.00 \mathrm{C}$ & 100 \\
\hline Chlorfenapyr & $0.0 \pm 0.00 \mathrm{C}$ & 100 & $0.0 \pm 0.00 \mathrm{C}$ & 100 & $0.0 \pm 0.00 \mathrm{C}$ & 100 & $0.0 \pm 0.00 \mathrm{C}$ & 100 & $0.0 \pm 0.00 \mathrm{C}$ & 100 \\
\hline Chlorfenapyr + Zeta-cypermethrin & $0.0 \pm 0.00 \mathrm{C}$ & 100 & $0.0 \pm 0.00 \mathrm{C}$ & 100 & $0.0 \pm 0.00 \mathrm{C}$ & 100 & $0.0 \pm 0.00 \mathrm{C}$ & 100 & $0.0 \pm 0.00 \mathrm{C}$ & 100 \\
\hline Zeta-cypermethrin & $5.0 \pm 0.00 \mathrm{~A}$ & 0 & $5.0 \pm 0.00 \mathrm{~A}$ & 0 & $2.3 \pm 0.48 \mathrm{~B}$ & 55 & $2.3 \pm 0.48 \mathrm{~B}$ & 55 & $2.3 \pm 0.48 \mathrm{~B}$ & 55 \\
\hline Control & $5.0 \pm 0.00 \mathrm{~A}$ & - & $5.0 \pm 0.00 \mathrm{~A}$ & - & $5.0 \pm 0.00 \mathrm{~A}$ & - & $5.0 \pm 0.00 \mathrm{~A}$ & - & $5.0 \pm 0.00 \mathrm{~A}$ & - \\
\hline $\mathrm{Cv}(\%)$ & 9.70 & & 9.70 & & 6.62 & & 4.20 & & 4.20 & \\
\hline
\end{tabular}

Note. ${ }^{1}(\mathrm{X} \pm \mathrm{SE})=$ Average number of caterpillars \pm Standard error. ${ }^{2}$ Means followed by the same letter in column do not differ by Tukey test $(\mathrm{P}<0.05)$. CV $(\%)=$ Coefficient of variation. 


\section{Discussion}

\subsection{Residual Contact Bioassay}

Chlorfenapyr is one of the insecticides that has been widely used for the control of various insect pests. The active principle is composed of a pro-insecticide and the removal of the N-ethoxymethyl group from the molecule converts it to the toxic form. In this condition, after the compound reaches the mitochondria causes losses of $\mathrm{H}+$ protons. As a consequence, the disorder affects the production of ATP resulting in lack of energy and death of the target insect (Roditakis et al., 2015).

The insecticides, with a mode of action in the nervous system, such as zeta-cypermethrin (pyrethroids), present a marked shock action in the different orders of insects (Guedes et al., 2012). However, the present study reveals that, when applied by residual pathway alone, it showed high control efficiency, soon after application.

In general, it was observed that the combination of flubendiamide combined with a pyrethroid showed better efficiency in the control of $S$. frugiperda caterpillars. The mode of action of the insecticides of the group of antranilícas diamides, to which belongs flubendiamide, bind to the rianodine receptors of the insects in the muscular cells, promoting the uncontrolled exit of calcium, due to the opening of the canal, provoking muscular paralysis and death of the insect (Cordova et al., 2006; Lahm et al., 2007; Arrue et al., 2014). When there is a combination with a shock product the efficiency tends to be better, due to the fast action of the product, since the group of diamides does not have this effect. Studies developed by Ebbinghaus et al. (2007) and Gerreiro et al. (30\%) and flubendiamide (50\%), attributing the fact that they require more time to cause mortality of the target.

The results found applied with residuals with the diamides, prove the difference in susceptibility of the population and can be used as a crucial tool for resistance management programs. In addition, the relevance of this study can contribute to analyze the behavior of genes related to resistance to insecticide through crosses between susceptible and resistant strains (Lima-Neto, 2016).

The diamides have been used in agriculture for several years, so there are reports of resistance to lepidopteran species, including cross-resistance (Thomas, 2013; Roditakis et al., 2015). The results indicate that due to prolonged field use, insects exhibit resistance to both flubendiamide and chlorantraniliprole due to competition for the same site of action and selection pressure (Gonçalves et al., 2016).

The insecticides to be registered in Brazil, the government agencies that regulate the release of chemical and biological products for the control of arthropod pests, require at least $80 \%$ efficiency in the control of the target species (Mapa, 2018), since the other $20 \%$ are attributed to the natural mortality of the species (Abbott, 1925). The results obtained in the experiments indicated a certain concern with the product that uses flubendiamide as active principle, since the efficiency was low, especially in the residual contact tests, in the direct contact test, the efficiency of $80 \%$ was only obtained at the end of the experiment test.

In order to be successful in controlling insects, integrated pest management (IPM) should be advocated, with one of the actions being the rotation of active ingredients (IRAC, 2018). However, the basic premise is the monitoring of the area, so that the decision is made at the right time, using methods that effectively interrupt herbivory and preserving natural enemies. One strategy that can be used in areas with high rates of infestation is the combination of one insect from the group of pyrethroids (knock down) and another insecticide of slower action and action at another site of action of the insect (Guerreiro et al. 2013). However, it is necessary to consider the variation of the susceptibility of the species when the insecticide is applied (Guedes et al., 2012).

Studies of insecticides for the control of Grapholita molesta (Busck, 1916) (Lepidoptera: Tortricidae) found that there is a reduction in insecticide susceptibility (Arioli et al., 2004). Silva (1999) demonstrated in corn cultivation that the control of $S$. frugiperda when it is carried out at the appropriate moment (most of the caterpillars in $2^{\text {nd }}$ instar) the control was of $88 \%$, and in the late form, there was a reduction of $33 \%$ in insect control. Therefore, it is evident that control should be directed to first instars caterpillars, not only because of the ease of control, but also because of the reduction of crop damage (Cruz, 2002).

Helicoverpa armigera (Hübner, 1808) (Lepidoptera: Noctuidae) causes damage to several crops in Brazil, with the use of insecticides being the most commonly used control method, which are, in general, the same active ingredients used for caterpillar- cartridge, so care must be taken in the use of these. In lethal concentration $\left(\mathrm{LC}_{50}\right)$ determinations, $H$. armigera has shown that chlorfenapyr $\left(0.0063 \mathrm{~g} \mathrm{to}^{-1}\right)$ and zeta-cypermethrin $(0.0242 \mathrm{~g}$ to $\mathrm{L}^{-1}$ ) are extremely and moderately toxic to caterpillars, respectively. In addition to the mortality test, chlorfenapyr and zeta-cypermethrin applied alone controlled approximately $80 \%$ of $\mathrm{H}$. armigera caterpillars at 72 hours, both by direct contact and residual contact (Laurenteis, 2017). 
In the present study, the combination of the two active principles (chlorfenapyr + zeta-cypermethrin) demonstrated compatibility, due to the increase of the control efficiency in addition, to present a greater range of management, that is, control for both instar caterpillars and of $5^{\text {th }}$ instar.

In some situations, the application of two combined products may lead to the occurrence of interactions that manifest in an additive, antagonistic or synergistic form, which may or may not affect control, as well as producing effects unknown to toxicology (Nash, 1967; Trezzi, 2005). The effects are manifested after the interaction of the active ingredients, which is seldom studied, perhaps due to the high number of products available in the market (Petter et al., 2013).

Factors such as the constant exposure of insect pests to certain active principles, intensive cultivation, expansion of the time and area of planting in traditional areas, emergence of new ecological conditions and niches and cultural practices have increased the cases of resistance in Brazil and in the insecticides (Diez-Rodriguez \& Omoto, 2001).

Thus, although diamides constitute a recent and innovative class of insecticides, there are reports of low susceptibility to flubendiamide for several species of Lepidoptera such as Heliothis virescens (Fabricius, 1781) (Lepidoptera: Noctuidae), Agrotis ipsilon (Hufnagel, 1766) (Lepidoptera: Noctuidae) (Zuo et al., 2018) and Plutella xylostella (Linnaeus, 1758) (Lepidoptera: Plutellidae) (Ribeiro et al., 2017).

Although there are significant advances in IPM programs, control of $S$. frugiperda continues to be carried out almost exclusively by chemical methods, which potentiates insect resistance (Diez-Rodriguez \& Omoto, 2001; Fazolin et al., 2017). Thus, there is a lack of studies on the mechanism of resistance of S. frugiperda in order to define management tactics that delay or even avoid the evolution of resistance (Ribeiro, 2014; Fernandes et al., 2017), since in the present work, flubendiamide presents concern for the low efficiency in the control when applied via residual.

Besides the concern to choose the correct active ingredient and to define the correct moment of application it is necessary to determine which application technology to adopt. In order to achieve adequate placement and distribution of the product in the required quantity, in an economical and minimal environmental contamination (Matuo, 1998; Bonadiman, 2008; Costa et al., 2017). In the results of the present study it was observed that the application form influenced the mortality time observed in the insects.

\subsection{Residual Contact Bioassay}

Because the $2^{\text {nd }}$ instar caterpillars receive the product via direct contact and are small, the amount of the product on the integument is greater, allowing the insecticides to penetrate through the cuticle, trachea and even pores and/or hair interconnected to the nervous system and , they act in the metabolism until death (Viana \& Costa, 1998) faster than in $5^{\text {th }}$ instar caterpillars. The lipophilic character of some insecticides associated with the thickness and lipid composition of the cuticle of the insects is responsible for the greater penetration of the product into the cuticle and its translocation until the action target, observed in the treatments in smaller caterpillars (Gusmão et al., 2000).

The application of flubendiamide + zeta-cypermethrin showed compatibility providing control efficiency of $S$. frugiperda in $2^{\text {nd }}$ instar. The same was observed in the previous experiment, applied by residual path in both $2^{\text {nd }}$ instar and $5^{\text {th }}$ instar caterpillars.

Resistance monitoring should be used to observe the evolution and behavior of insect populations against an active ingredient. Studies carried out in eight Brazilian states showed that S. frugiperda populations showed high susceptibility to chlorantraniliprole and flubendiamide in the 2011/2012 crop. However, variations in survival from $0 \%$ to $12.7 \%$ for chlorantraniliprole and from $1 \%$ to $6 \%$ for flubendiamide were observed according to the crop and locality (Ribeiro, 2014).

When they reproduce, there is transmission of the genes responsible for the resistance to the offspring and, gradually, the population becomes less susceptible to the active principle. For treatment with flubendiamide, it is expected that there is a greater chance of insects developing resistance, due to the performance in the control of the carcass caterpillar compared to the other products used in the study (Bravo \& Soberón, 2008; Huang et al., 2011; IRAC, 2018).

The results evidenced a high mortality, with emphasis on the treatments involving chlorfenapyr, regardless of the mode of application and instar of the insect. Neurotoxic insecticides, when used in combination with other insecticides, have generally increased relative efficacy on S. frugiperda mortality in up to 48 hours (Cessa et al., 2013). 
However, the study emphasizes the producer's concern with the mode of action of each product, besides equipment calibration, droplet diameter that contribute to uniform distribution and effective control of the target (Souza et al. 2016; Gonçalves et al., 2016). However, the management of insecticides should also be considered, because if the producer does not adopt, there will be selection of resistant individuals and lose efficiency of the active principle. The result is the early withdrawal of technology from the market, with losses for both industry and producers.

\section{Conclusion}

The best performance is attributed to the treatment using chlorfenapyr, regardless of the mode of application and instar of the target insect.

\section{References}

Abbott, W. S. (1925). A method of computing the effetiveness of the insecticide. Journal Economic Entomology, 18(2), 265-267. https://doi.org/10.1093/jee/18.2.265a

Ahmad, M., Farid, A., \& Saeed, M. (2018). Resistance to new insecticides and their synergism in Spodoptera exigua (Lepidoptera: Noctuidae) from Pakistan. Crop Protection, 107(1), 79-86. https://doi.org/10.1016/ j.cropro.2017.12.028

Arioli, C. J., Botton, M., \& Carvalho, G. A. (2004). Controle químico da Grapholita molesta (Busck) (Lepidoptera: Tortricidae) na cultura do pessegueiro. Ciência Rural, 34(6), 1695-1700. https://doi.org/ $10.1590 / \mathrm{S} 0103-84782004000600005$

Arrue, A., Guedes, J. V. C., Storck, L., Swarowsky, A., Cagliari, D., Burtet, L. M., \& Arnemann, J. A. (2014). Precipitação artificial após aplicação do inseticida clorantraniliprole associado com adjuvante em plantas de soja. Ciência Rural, 44(12), 2118-2123. https://doi.org/10.1590/0103-8478cr20120211

Belluzzo, L. G. M., Frischtak, C. R., \& Laplane, M. (2014). Produção de Commodities e Desenvolvimento Econômico (p. 126). Campinas: UNICAMP, Instituto de Economia.

Bonadiman, R. (2008). Pontas de pulverização e volumes de calda no controle de Anticarsia gemmtalis (Hübner, 1818) e Piezodorus guildinii (Westwood, 1837) na cultura da soja Glycine max (Master's theses, Federal University of Santa Maria, Santa Maria, Brazil).

Bravo, A., \& Soberón, M. (2008). How to cope with insect resistence to Bt toxins? Trends in Biotechnology, 26(1), 573-579. https://doi.org/10.1016/j.tibtech.2008.06.005

Cessa, R. M. A., Melo, E. P., \& Lima, J. R. I. S. (2013). Mortalidade de Spodoptera frugiperda (J. E. Smith) (Lepdoptera: Noctuidae) alimentadas com folhas de milho e feijoeiro imersas em soluções contendo inseticidas. Revista Agrogeoambiental, 5(1), 85-92. https://doi.org/10.18406/2316-1817v5n12013434

CONAB (Companhia Nacional de Abastecimento). (2018). Observatório Agrícola. 2017/2018—Décimo primeiro levantamento (pp. 1-145). Brasília: Ministério da Agricultura, Pecuária e Abastecimento.

Cordova, D., Benner, E. A., Sacher, M. D., Rauh, J. J., Sopa, J. S., Lahm, G. P., \& Selby, T. P. (2006). Anthranilic diamides: a new class of insecticides with a novel mode of action, ryanodine receptor activation. Pesticide Biochemistry Physiology, 84(1), 196-214. https://doi.org/10.1016/j.pestbp.2005.07.005

Costa, L. L., Carneiro, A. L. C. G., Souza, A. D. V., Almeida, D. P., \& Ferreira, M. C. (2017). Caracterização da aplicação com diferentes inseticidas e pontas de pulverização na cultura da soja. Revista Engenharia na Agricultura, 25(2), 116-123. https://doi.org/10.13083/reveng.v25i2.732

Cruz, I. (2002). Manejo da resistência de insetos-praga a inseticidas, com ênfase em Spodoptera frugiperda (Smith) (p. 15). Sete Lagoas: Embrapa Milho e Sorgo.

Diez-Rodríguez, G. I., \& Omoto, C. (2001). Herança da Resistência de Spodoptera frugiperda (J. E. Smith) (Lepidoptera: Noctuidae) a Lambda-Cialotrina. Neotropical Entomology, 30(2), 311-316. https://doi.org/10. 1590/S1519-566X2001000200016

Ebbinghaus, D., Schnorbach, H. J., \& Elbert, A. (2007). Field development of flubendiamide (Belt®, Fame ${ }^{\circledR}$, Fenos ${ }^{\circledR}$, Amoli $\left.{ }^{\circledR}\right)$ - A new insecticide for the control of lepidopterous pests. Pflanzenschutz-Nachrichten Bayer, 60(2), 219-246.

Fazolin, M., Estrela, J. L. V., Monteiro, A. F. M., Silva, I. M., \& Gomes, L. P. (2017). Sinérgico alternativo para inseticidas inibidores de acetilcolinesterase.Revista Agro@mbiente, 11(3), 232-240. https://doi.org/ 10.18227/1982-8470ragro.v11i3.3995 
Fernandes, F. O., Abreu, J. A., Christi, L. M., Rodrigues-Filho, J. A., Martins, A., \& Rosa, A. P. S. A. (2017). Desenvolvimento de Spodoptera frugiperda (Smith, 1797) em cultivares de milho em laboratório (p. 35). Pelotas: Embrapa Clima Temperado (Boletim de Pesquisa e Desenvolvimento, 264).

Gonçalves, G. S., Cardoso, R. S., Oliveira, W. S. A., Cessa, R. M. A., \& Melo, E. P. (2016). Eficiência de inseticidas no controle de Spodoptera frugiperda (J. E. Smith) (Lepidoptera: Noctuidae) alimentadas com folhas de milho, feijão, soja e sorgo. Enciclopédia Biosfera, 13(23), 549-559. https://doi.org/10.18677/ Enciclopedia_Biosfera_2016_049

Greene, G. L., Leppla, N. C., \& Dickerson, W. A. (1976). Velvetbean caterpillar: A rearing procedure and artificial medium. Journal Economic Entomology, 69(4), 487-497. https://doi.org/10.1093/jee/69.4.487

Guedes, J. V. C., Fiorin, R. A., Sturmer, G. R., Prá, E. D., Perini, C. R., \& Bigolin, M. (2012). Sistemas de aplicação e inseticidas no controle de Anticarsia gemmatalis na soja. Revista Brasileira Engenharia Agrícola e Ambiental, 16(8), 910-914. https://doi.org/10.1590/S1415-43662012000800014

Guedes, R. N. C., \& Oliveira, E. E. (2002). Resistência a inseticidas-pragas do cafeeiro: Situação e perspectivas, In L. Zambolim (Eds.), O estado da arte de tecnologias na produção de café (pp. 471-497). Viçosa: Universidade Federal de Viçosa.

Guerreiro, J. C., Camolese, P. H., \& Busoli, A. C. (2013). Eficiência de inseticidas associados a enxofre no controle de Spodoptera frugiperda em milho convencional. Revista Scientia Agraria Paranaensis, 12(4), 275-285. https://doi.org/10.18188/1983-1471/sap.v12n4p275-285

Gusmão, M. R., Picanço, M., Gonring, A. H. R., \& Moura, M. F. (2000). Seletividade fisiológica de inseticidas a vespidae predadores do bicho-mineiro-do-cafeeiro. Pesquisa Agropecuária Brasileira, 35(4), 681-686. https://doi.org/10.1590/S0100-204X2000000400002

Huang, F., Ghimire, M. N., Leonard, B. R., Wang, J., Daves, C., Levy, R., ... Ferguson, R. (2011). F2 screening for resistence to pyramided Bacillus thuringiensis maize in Louisiana and Mississippi populations of Diatraea saccharalis (Lepidoptera: Crambidae). Pest Management Science, 67(10), 1269-1267. https://doi.org/10.1002/ps.2182

IBAMA. (2017). Relatório de comercialização de agrotóxicos. Retrieved from http://www.ibama.gov.br/ agrotoxicos/relatorios-de-comercializacao-de-agrotoxicos\#sobreosrelatorios

IRAC. (2018). Manejo de resistência a inseticidas-Um assunto estratégico para a agricultura brasileira. Retrieved from http://www.irac-br.org/single-post/2015/03/05/Manejo-da-Resist\%C3\%AAncia-a-Inseticida S-\%E2\%80\%93-um-assunto-estrat \%C3\%A9gico-para-a-agricultura-brasileira

Lahm, G. P., Stevenson, T. M., Selby, T. P., Freudenberger, J. H., Cordova, D., Flexner, L., ... Benner, E. A. (2007). Rynaxypyr(tm): A new insecticidal anthranilic diamide that acts as a potent and selective ryanodine receptor activator. Bioorganic \& Medicinal Chemistry Letters, 17(22), 6274-6279. https://doi.org/10.1016/ j.bmcl.2007.09.012

Laurentis, V. L. (2017). Helicoverpa armigera (Hübner) (Lepidoptera: Noctuidae): Táticas para o manejo integrado (Doctorate thesis, Paulista State University, Faculty of Agrarian and Veterinary Sciences, Jaboticabal, Brazil). Retrieved from https://repositorio.unesp.br/handle/11449/148862

Lima-Neto, J. E. (2016). Bases para o manejo da resistência de Plutella xylostella (L.) (Lepidoptera: Plutellidae) a inseticidas: Ssuscetibilidade e genética da resistência a clorfenapir (Doctorate thesis, Rural Federal University of Pernambuco, Recife, Brazil). Retrieved from http://www.ppgea.ufrpe.br/sites/ww2.ppgea. ufrpe.br/files/documentos/jaconias_escocio_lima_neto.pdf

Lucchini, F. (1977). Biologia da Spodoptera frugiperda (Smith e Abbott, 1797) (Lepidoptera, Noctuidae). Niveis de prejuizos e avaliacao toxicologica de inseticidas para o seu combate, em milho (Master's theses, Federal University of Paraná, Curitiba, Brazil). Retrieved from http://www.bdpa.cnptia.embrapa.br/consulta/busca? $\mathrm{b}=$ ad\&id=564896\&biblioteca=vazio\&busca=autoria:\%22LUCCHINI,\%20F.\%22\&qFacets=autoria:\%22LU CCHINI,\%20F.\%22\&sort=\&paginacao=t\&paginaAtual $=1$

MAPA (Ministério da Agricultura, Pecuária e Abastecimento). (2018). Memória da $2^{a}$ reunião técnica nacional sobre pesquisa com agrotóxicos (pp. 1-6). Brasília.

Matuo, P. M. (1998). Fundamentos da tecnologia de aplicação de agrotóxicos. In J. V. C. Guedes, \& S. H. B. Dornelles (Eds.), Tecnologia e segurança na aplicação de agrotóxicos: novas tecnologias (pp. 95-105). Santa Maria: Departamento de Defesa Fitossanitária, Sociedade de Agronomia de Santa Maria. 
Melo, M., Brandão, A., \& Lima, J. (2018). Relação entre sociedade e natureza e desdobramentos do agronegócio na contemporaneidade. Revista Geográfica Acadêmica, 12(1), 36-49.

Michelotto, M. D., Crosariol-Neto, J., Pirotta, M. Z., Duarte, A. P., Feitas, R. S., \& Finoto, E. L. (2017). Eficácia de milho transgênico tratado com inseticida no controle da lagarta-do-cartucho no milho safrinha no estado de São Paulo, Brasil. Ciência e Agrotecnologia, 41(2), 128-138. https://doi.org/10.1590/1413-705420 17412020816

Nash, R. G. (1967). Phytotoxic pesticide interactions in soil. Agronomy Journal, 59(3), 227-230. https://doi.org/ 10.2134/agronj1967.00021962005900030006x

Petter, F. A., Segate, D., Almeida, F. A., Neto, F. A., \& Pacheco, L. P. (2013). Incompatibilidade física de misturas entre inseticidas e fungicidas. Comunicata Scientiae, 4(2), 129-138.

Qi, S., \& Casida, J. E. (2013). Species differences in chlorantraniliprole and flubendiamide insecticide binding sites in the ryanodine receptor. Pesticide Biochemistry and Physiology, 107(3), 321-326. https://doi.org/ 10.1016/j.pestbp.2013.09.004

Ribeiro, L. M. S., Siqueira, H. A. A., Teixeira, V. W., Ferreira, H. N., Silva, W. M., Silva, J. E., \& Teixeira, A. A. C. (2017). Field resistance of Brazilian Plutella xylostella to diamides is not metabolism-mediated. Crop Protection, 93(1), 82-88. https://doi.org/10.1016/j.cropro.2016.11.027

Ribeiro, R. S. (2014). Monitoramento da suscetibilidade de populações de Spodoptera frugiperda (J.E. Smith) (Lepidoptera: Noctuidae) a inseticidas diamidas no Brasil (Master's theses, University of Agriculture Luiz de Queiroz, Piracicaba, Brazil). Retrieved from http://www.teses.usp.br/teses/disponiveis/11/11146/tde-111 12014-153823/en.php

Roditakis, E., Vasakis, E., Grispou, M., Stavrakaki, M., Nauen, R., Gravouil, M., \& Bassi, A. (2015). First report of Tuta absoluta resistance to diamide insecticides. Journal of Pest Science, 88(1), 9-16. https://doi.org/ 10.1007/s10340-015-0643-5

Rolim, R. R., Pinto, A. A., Camara, F. T., Mota, A. M. D., \& Silva, C. S. (2018). Produtividade e rentabilidade do milho em função do manejo da adubação na região do Cariri-Ce. Revista Cientifica Rural, 20(1), 204-221.

SAS University. (2014). SAS® 9.4 Statements (3rd ed.). SAS Instit. Inc., USA. Retrieved from https://www.sas.com/en_us/software/university-edition.html

Silva, M. T. B. (1999). Fatores que afetam a eficiência de inseticidas sobre Spodoptera frugiperda Smith em milho. Ciência Rural, 29(3), 383-387. https://doi.org/10.1590/S0103-84781999000300001

Sosa-Gómez, D. R., \& Omoto, C. (2012). Resistência a inseticidas e outros agentes de controle em artrópodes associados à cultura da soja. In C. B. Hoffmann-Campo, B. S. Corrêa-Ferreira, \& F. Moscardi (Eds.), Soja: Manejo integrado de insetos e outros artrópodes-praga (Cap. 10, p. 673-723). Londrina, Embrapa Soja.

Souza, R. T., Palladini, L. A., \& Ferreira, M. C. (2016). Tecnologia de aplicação de agrotóxicos. In L. R. Garrido, A. Hoffmann, \& S. V. Silveira (Eds.), Produção integrada de uva para processamento: Manejo de pragas e doenças (Vol. 4, Cap. 4, pp. 71-85). Bento Gonçalves, Embrapa Uva e Vinho.

Thomas, P. S., George, P. L., Thomas, M. S., Kenneth, A. H., Daniel, C. I., Billy, A., ... Pahutski, T. F. (2013). Discovery of cyantraniliprole, a potent and selective anthranilic diamide ryanodine receptor activator with cross-spectrum insecticidal activity. Bioorganic \& Medicinal Chemistry Letters, 23(23), 6341-6345. https://doi.org/10.1016/j.bmcl.2013.09.076

Trezzi, M. M., Filippi, C. L., Nunes, A. L., Carnieleto, C. E., \& Ferreira. A. R. J. (2005). Eficácia de controle de plantas daninhas e toxicidade ao milho da mistura de Foramsulfuron e Iodosulfuron isoladamente ou em associação com Atrazine e/ou Clorpirifós. Planta Daninha, 23(4), 653-659. https://doi.org/10.1590/ S0100-83582005000400013

Viana, P. A., \& Costa, E. F. (1998). Controle da lagarta-do-cartucho, Spodoptera frugiperda (J. E. Smith) (Lepidoptera: Noctuidae) na cultura do milho com inseticidas aplicados via irrigação por aspersão. Anais da Sociedade Entomológica do Brasil, 27(3), 451-458. https://doi.org/10.1590/S0301-80591998000300014

Wang, X., Xiang, X., Yu, H., Liu, S., Yin, Y., Cui, P., ... Yang, Q. (2018). Monitoring and biochemical characterization of beta-cypermethrin resistance in Spodoptera exigua (Lepidoptera: Noctuidae) in Sichuan Province, China. Pesticide Biochemistry and Physiology, 146(1), 71-79. https://doi.org/10.1016/j.pestbp. 2018.02.008 
Zuo, Y., Wang, H., Xu, Y., Huang, J., Wu, S., Wu, Y., \& Yang, Y. (2018). CRISPR/Cas9 mediated G4946E substitution in the ryanodine receptor of Spodoptera exigua confers high levels of resistance to diamide insecticides. Insect Biochemistry and Molecular Biology, 89(1), 79-85.

\section{Copyrights}

Copyright for this article is retained by the author(s), with first publication rights granted to the journal.

This is an open-access article distributed under the terms and conditions of the Creative Commons Attribution license (http://creativecommons.org/licenses/by/4.0/). 